\title{
ANALISIS PERBANDINGAN RASIO RENTABILITAS PADA BANK MANDIRI TAHUN 2017-2019
}

\author{
Siti Taformasi Saidyah Permata Sari, Yosep Eka Putra \\ Akademi Keuangan dan Perbankan "Pembangunan" Padang \\ Sitisaidyah1918@gmail.com
}

\begin{abstract}
The purpose of this study is to find out how the ratio of profitability at Bank Mandiri. Data collection methods used by means of literature study. Data analysis methods used are qualitative analysis methods. The results of this study indicate that the bank ROA level is still in a Good or Healthy position. ROE also shows that the bank is in good condition in managing the company's finances. The bank NPM is still in a good or healthy position. In the third financial position this ratio can be categorized as Good or Healthy. So Bank Mandiri has reached the standard PBI regulation No. 15 / PBI / 2013.
\end{abstract}

Keywords : Rentability, Return On Asset (ROA), Return On Equity (ROE), Net Profit Margin (NPM).

\section{PENDAHULUAN}

Menurut Undang - undang Nomor 10 Tahun 1998 mengenai perubahan tentang perbankan pada Undang - undang Nomor 7 Tahun 1992 Bank adalah badan usaha yang melakukan penghimpunan dana dari masyarakat dalam bentuk simpanan dan menyalurkannya kembali kepada masyarakat dalam bentuk kredit ataupun bentuk-bentuk yang lain pada rangka untuk peningkatan taraf hidup rakyat banyak. Jenis bank berdasarkan UU No. 10 tahun 1998 tentang perubahan UU No. 7 tahun1992 ada dua jenis yaitu: Bank yang melakukan usaha secara konvensional dan bank yang melakukan secara syariah.

Bank konvensional dapat didefinisikan seperti pengertian bank umum pada pasal 1 ayat 3 Undang - undang No. 10 Tahun 1998 dengan menghilangkan kalimat "dan atau berdasarkan prinsip syariah", yaitu bank yang melaksanakan kegiatan usaha secara konvensional dalam memberikan suatu jasa dalam lalu lintas pembayaran. Berdasarkan UU RI No. 21 tahun 2008 perbankan syariah adalah segala sesuatu yang menyangkut bank syariah dan unit usaha Syariah, mencakup kelembagaan, kegiatan usaha, serta cara dan proses dalam melaksanakan kegiatan usahanya.

Bank Mandiri merupakan Bank yang beroperasi sebagai penyedia jasa keuangan di indonesia. Layanannya meliputi pembiayaan perdagangan, valuta asing, dan jasa kustodian, pengolahan kas, proses pembayarannya kartu debit dan kredit. Bank ini menyediakan solusi keuangan lengkap untuk perusahaan swasta dan pemerintah, komersil,usaha kecil, dan mikro dan juga pelanggan ritel.

Menurut (Mila Mirza, 2019) Laporan keuangan adalah laporan yang berisikan bagian dari pelaporan keuangan. Diantaranya meliputi neraca, laporan 
laba rugi, laporan posisi keuangan yang disajikan pada berbagai tata cara, contohnya sebagai laporan arus kan atau laporan arus dana.

Menurut (Roza \& Fernos, 2014) Laporan Keuangan adalah dua daftar yang disusun oleh akuntan pada akhir periode untuk suatu perusahaan. Kedua daftar itu adalah daftar neraca atau daftar periode keuangan dan daftar pendapatan atau daftar laba- rugi. Pada akhir - akhir ini sudah menjadi kebiasaan bagi perseroan - perseroan untuk menambahkan daftar kegiatan yaitu daftar surplus daftar laba yang tidak dibagikan (laba yang ditahan). Menurut (Pradnyani et al., 2017) laporan keuangan bank merupakan bentuk dari pertanggungjawaban perusahaan terhadap pihak-pihak yang berkepentingan dengan kinerja bank yang dicapai selama periode tertentu.

Menurut (Mila Mirza, 2019) Bank yang dapat dikatakan sehat dapat dilihat secara rentabilitas dimana nilainya terus mengalami peningkatan, hal ini juga dikaitkan dengan efisiensi dan kemampuan bank dalam menjalankan kegiatan operasinya, sehingga apabila efisiensi biaya dilakukan, maka keuntungan yang diperoleh oleh suatu bank juga akan semakin besar. Kinerja operasinya yang baik diharapkan dapat membantu meningkatkan pertumbuhan keuangan secara efektif dan efisiensi.

Pengertian analisis menurut kamus istilah keuangan dan investasi adalah metode analisis yang digunakan dalam membuat penilaian kredit dan investasi dan menggunakan hubungan antara angka-angka yang ditemukan dalam laporan keuangan untuk menentukan nilai yang mengkaji risiko, rasio-rasio tersebut dibandingkan dengan rasio masa sebelumnya serta rasio perusahaan lain agar dapat mengungkapkan kecenderungan dan mengidentifikasi kejanggalan.

Analisis laporan keuangan melibatkan penggunaan berbagai macam laporan keuangan yang terdiri atas bagian tertentu mengenai suatu informasi yang penting (Fernos \& Dona, 2018).

Rasio Rentabilitas adalah rasio yang digunakan untuk mengukur dari suatu perusahaan dalam menghasilkan suatu laba dari suatu perusahaan selama periode tertentu. Sedangkan menurut (Hapsak, 2018) Rasio rentabilitas merupakan penilaian terhadap kemampuan bank untuk mendukung kegiatan Operasionalnya dan permodalannya. Rasio rentabilitas dapat dihitung menggunakan, Return on Assets (ROA), Return On Equity (ROE), Net Profit Margin (NPM).

Bank Mandiri dapat dinilai bagaimana tingkat kesehatan pada bank tersebut, yang mana perlu dilakukan penilaian terhadap faktor-faktor yang menentukan tingkat kesehatan bank. Dari Tabel diatas Dapat dilihat bahwa selama Tiga tahun tingkat kesehatan pada Bank Mandiri mengalami penurunan pada tingkat kestabilan.

Penulis tertarik untuk mengetahui bagaimana kemampuan Bank Mandiri dalam menggunakan modalnya secara efisien serta dalam menggunakan aktivanya secara produktif untuk menghasilkan laba selama periode tertentu dengan tujuan perusahaan tersebut dapat beroperasi secara stabil dan mampu mengembalikan semua hutang-hutangnya kepada pihak lain. Maka penulis berkeinginan untuk menganalisis laporan keuangan pada Bank Mandiri. Untuk itu, penulis tertarik menganalisi "Analisis Perbandingan Rasio Rentabilitas Pada Bank Mandiri" 
Tabel 1

Data Laporan Keuangan

Bank Mandiri

Tahun 2017-2019

\begin{tabular}{|c|c|c|c|}
\hline \multirow[t]{2}{*}{ KETERANGAN } & \multicolumn{3}{|c|}{ TAHUN } \\
\hline & 2017 & 2018 & 2019 \\
\hline ROA & $\operatorname{Rp} 56,95 \%$ & Rp 66,97\% & $\operatorname{Rp} 60,58 \%$ \\
\hline ROE & $\operatorname{Rp} 50,35 \%$ & Rp 60,32\% & $\operatorname{Rp} 60,22 \%$ \\
\hline NPM & Rp 39,07\% & $\operatorname{Rp} 51,08 \%$ & $\operatorname{Rp} 47,50 \%$ \\
\hline
\end{tabular}

\section{Grafik Perbandingan Rasio Rentabilitas Tahun 2017-2019}

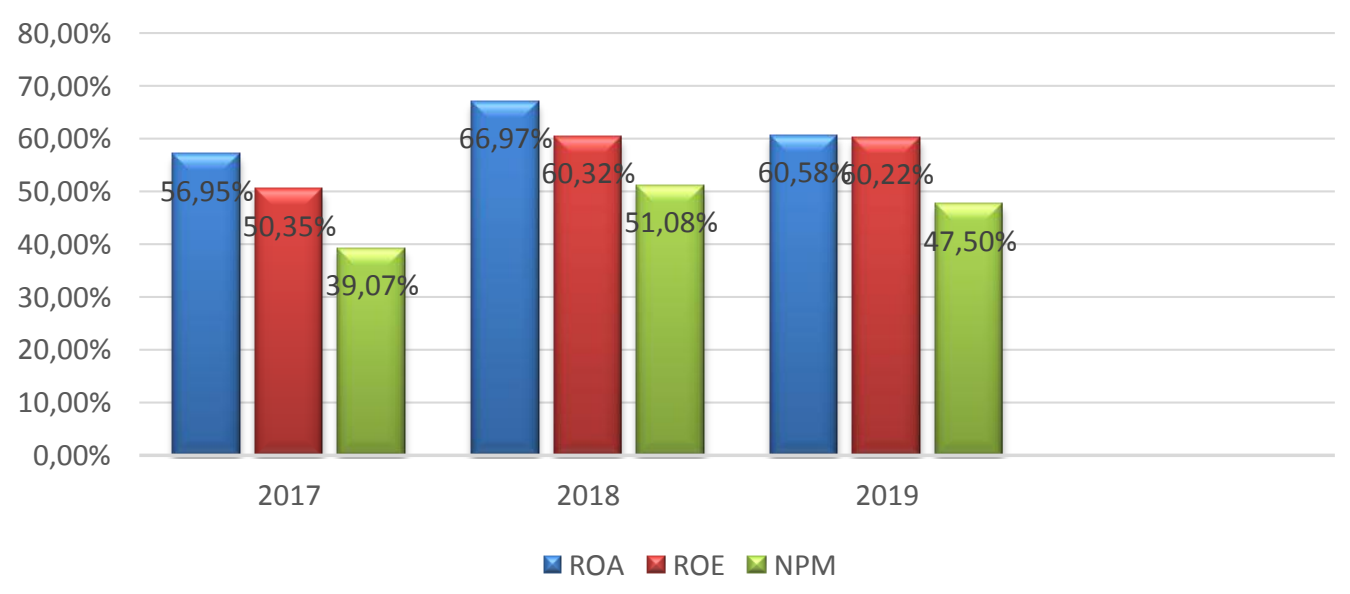

Keterangan:

Jadi dilihat dari grafik diatas bahwa rasio Return On Asset dari tahun ke 2017 ke tahun 2018 mengalami kenaikan sedangkan ROA pada tahun 2019 mengalami penurunan, walaupun ROA pada Bank Mandiri tahun ke tahun mengalami naik turun, tapi bank ini dapat dikatakan baik, karena ROA pada Bank Mandiri sudah mencapai standar ketentuan PBI No. 15/7/PBI/2013 yaitu sebesar $5,08 \%$. Semakin tinggih nilai dari ROA, maka semakin efisien pula bank tersebut dalam memanfaatkan aktivanya untuk menghasilkan keuntungan sebelum pajak.

Return On Equity yang dapat dilihat dari grafik diatas bahwa rasio ROE dari tahun 2017 ke tahun 2018 mengalami kenaikan, sedangkan pada tahun 2019 bank mandiri mengalami penurunan. maka ROE pada Bank Mandiri dapat dikatakan baik, karena ROE pada Bank Mandiri sudah mencapai standar ketentuan BI yaitu sebesar 8,32\%.

Net Profit Margin yang dapat dilihat dari grafik diatas bahwa rasio NPM dari tahun 2017 ke tahun 2018 mengalami kenaikan sedangkan NPM pada tahun 2019 mengalami penurunan, walaupun mengalami naik turun NPM pada Bank 
Mandiri dapat dikatakan baik, karena NPM pada Bank Mandiri sudah mencapai standar ketentuan PBI No. 15/7/PBI/2013 yaitu sebesar 3,92\%.

\section{LANDASAN TEORI \\ Pengertian Bank}

Menurut Syaifuddin (2007) bank merupakan sebagai lembaga yang memediasi antar pihak surplus dana dengan pihak definisit dana. Pihak surplus dana ini adalah seseorang masyarakat yang mempunyai uang lebih dapat disimpan di bank dalam bentuk: giro, deposito, dan tabungan. Sedangkan pihak defisit dana adalah seorang masyarakat yang mengalami kekurangan uang atau kekurangan dana yang dapat dipenuhi dengan cara meminjam di Bank dalam bentuk kredit (loan).

\section{Pengertian Bank Mandiri}

Bank yang beroperasi sebagai penyedia jasa keuangan di indonesia. Layanannya meliputi pembiayaan perdagangan, valuta asing, dan jasa kustodian, pengolahan kas, proses pembayarannya kartu debit dan kredit. Bank ini menyediakan solusi keuangan lengkap untuk perusahaan swasta dan pemerintah, komersil,usaha kecil, dan mikro dan juga pelanggan ritel.

\section{Tujuan Bank Mandiri}

Melaksanakan kebijaksanaan dan program Pemerintah di bidang ekonomi dan pembangunan nasional pada umumnya, khusnya di bidang perbankan dengan menerapkan prinsip-prinsip yang terbatas.

\section{Pengertian laporan Keuangan}

Menurut (Maith, 2013) laporan keuangan merupakan laporan yang menunjukkan kondisi dari keuangan perusahaan pada periode tahun ini atau pada periode tertentu . Laporan keuangan merupakan hasil dari akhir proses pencatatan yang merupakan ringkasan dari transaksi-transaksi keuangan yang terjadi pada tahun buku yang bersangkutan.

Komponen - komponen dari Laporan keuangan yang tujuan umumnya terdiri atas sebagai berikut:

1. Neraca

Neraca yang diperlukan perusahaan sendiri yang terdiri dari tiga hal paling utama. Tiga hal yang dimaksud adalah Aktiva, Passiva dan modal. Dimana tiga hal yang telah disebutkan haruslah berada dalam keadaan seimbang demi kebaikan perusahaan itu sendiri. Seperti Aktiva itu diletakkan sebelah kiri, dan Passiva ditambah dengan modal diletakkan sebelah kanan.

2. Laporan Laba rugi

Laporan laba rugi merupakan perpaduan antara pemasukan dan pengeluaran yang harus dikeluarkan oleh perusahaan yang bersangkutan, yang menunjukkan kinerja operasional perusahaan selama periode tertentu.

3. Laporan Perubahan Ekuitas

Laporan perubahan ekuitas menunjukkan detail perusahaan yang terjadi, seperti setoran modal atau perolehan laba neto. Struktur dalam pembuatan laporan perubahan ekuitas ini terdiri dari investasi, saldo laba dan rugi hingga kepemilikan pribadi. 
4. Laporan Arus Kas

Laporan arus kas merupakan laporan yang menyajikan informasi mengenai tentang arus kas masuk dan arus kas keluar, dan setara kas suatu entitas untuk suatu periode tertentu. Melalui laporan arus kas, pengguna laporan keuangan ingin mengetahui bagaimana entitas menghasilkan dan menggunakan kas serta kas.

5. Catatan Atas Laporan Keuangan

Catatan atas laporan keuangan merupakan pengungkapan (disclosure), baik yang bersifat keuangan maupun non keuangan, dari akun-akun yang dilaporkan atau peristiwa yang dihadapi oleh peristiwa yang dihadapi oleh peristiwa yang dapat mempengaruhi posisi dan kinerja keuangan perusahaan, sehingga sering kali ditekankan bahwa catatan atas laporan keuangan merupakan bagian yang tidak terpisahkan dari laporan keuangan secara keseluruhan.

\section{Pengertian Rentabilitas}

Rasio Rentabilitas merupakan sebuah pengukuran terpenilaian terhadap kemampuan bank untuk menilai kegiatan Operasionalnya atau aktifitas bank apakah telah dilakukan dengan baik agar bank dapat memperoleh laba atau keuntungan yang maksimal (Sumitra \& Ibrahim, 2016). Rasio Rentabilitas merupakan kemampuan perusahaan dalam menghasilkan laba yang akan dibandingkan dengan modal yang dipergunakan aktiva atau modal yang akan menghasilkan laba tersebut. Dengan kata lain rentabilitas sering digunakan untuk mengukur kemampuan dari suatu perusahaan dalam menghasilkan laba dalam waktu periode tertentu.

\section{METODE PENELITIAN}

Dalam pengumpulan data dan bahan untuk bahan penelitian ini digunakan metode penelitian sebagai berikut :

\section{Metode Pengumpulan Data}

Di dalam penelitian ini penulis menggunakan metode pengumpulan data dengan cara yaitu:

Studi Pustaka (Library Rrsearch)

Penelitian ini dilakukan dengan cara mempelajari buku-buku, artikel-artikel, bacaan laporan-laporan dan publikasi yang berhubungan dengan objek penelitian.

\section{Metode analisis Data}

Dalam menganalisa data, penulis menggunakan metode analisa deskriptif yaitu dengan menguraikan data secara sistematis dari fakta-fakta yang didapat kemudian dihubungkan dengan analisis perbandingan rasio rentabilitas pada Bank Mandiri.

\section{HASIL DAN PEMBAHASAN}

\section{Analisis Terhadap Return on Asset (ROA)}

Return on Asset (ROA) rasio ini berguna untuk mengukur seberapa efisiensinya suatu perusahaan untuk mengubah uang yang akan digunakan untuk membeli Asset menjadi laba bersih. Semakin tinggi tingkat ROA suatu bank, 
semakin besar pula tingkat keuntungan yang akan diperoleh oleh bank tersebut dan semakin baik pula posisi bank tersebut dari segi penggunaan Asset (Mila Mirza, 2019). Menurut ketentuan PBI No. 15/7/PBI/2013 berlaku sejak 1 Oktober 2013 tingkat penilaian kesehatan Rasio Rentabilitas bank pada ROA yaitu dengan skor minimal 5,08\%. Berdasarkan data yang diperoleh ROA Bank Mandiri pada tahun 2017-2019 ditunjuk pada tabel dibawah ini sebagai berikut:

\section{Tabel 2}

Laba Bersih Sebelum Pajak Dan Total Aktiva

Bank Mandiri

Tahun 2017-2019

(Dalam Rupiah)

\begin{tabular}{|l|l|l|c|}
\hline \multicolumn{1}{|c|}{ Komponen } & $\mathbf{2 0 1 7}$ & $\mathbf{2 0 1 8}$ & $\mathbf{2 0 1 9}$ \\
\hline \begin{tabular}{l} 
a. $\begin{array}{l}\text { Laba Bersih } \\
\text { sebelum } \\
\text { Pajak }\end{array}$ \\
\hline b. Total Aktiva
\end{tabular} & 44.098 .065 & 31.320 .082 & 32.430 .770 \\
\hline
\end{tabular}

Sumber: www.ojk.go.id

Dengan Formula:

ROA $=\frac{\text { Laba Sebelum Pajak }}{\text { Total aktiva }} \times 100 \%$

1. Perhitungan ROA tahun 2017

$$
\begin{aligned}
R O A & =\frac{\operatorname{Rp} 25.098 .065}{\operatorname{Rp~44.067.021}} \times 100 \% \\
& =56,95 \%
\end{aligned}
$$

Artinya angka diatas menggambarkan bahwa Bank Mandiri menghasilkan laba sebelum pajak dengan menggunakan nilai ROA sebesar 56,95\% dengan arti bahwa setiap Rp 100 aktiva yang dimilikinya, Bank Mandiri mampu menghasilkan laba bersih sebelum pajak sebesar Rp 0,5695. Artinya Bank Mandiri efisien atau dapat dikatakan baik dalam menghasilkan laba setelah pajak, karena sudah mencapai standar dari ketentuan PBI No. 15/7/PBI/2013 berlaku sejak 1 Oktober 2013 yaitu sebesar 5,08\%, karena semakin tinggi nilai dari ROA, maka semakin efisien bank dalam memanfaatkan aktivanya untuk menghasilkan keuntungan sebelum pajak.

2. Perhitungan ROA tahun 2018

$$
\begin{aligned}
R O A & =\frac{\mathrm{Rp} 31.320 .082}{R p 46.767 .089} \times 100 \% \\
& =66,97 \%
\end{aligned}
$$

Artinya angka diatas menggambarkan bahwa Bank Mandiri menghasilkan laba sebelum pajak dengan menggunakan nilai ROA sebesar 66,97\% dengan arti bahwa setiap Rp 100 aktiva yang dimilikinya, Bank Mandiri mampu menghasilkan laba bersih sebelum pajak sebesar Rp 0,6697. Artinya Bank Mandiri sudah efisien atau dapat dikatakan baik, karena sudah mencapai standar dari ketentuan PBI No. 15/7/PBI/2013 berlaku sejak 1 Oktober 2013 yaitu sebesar 5,08\%, karena semakin tinggi 
nilai ROA, maka semakin efisien pula bank dalam memanfaatkan aktivanya untuk menghasilkan keuntungan sebelum pajak.

3. Perhitungan ROA tahun 2019

$$
\begin{aligned}
R O A= & \frac{\mathrm{Rp} 32.430 .770}{\mathrm{Rp} 53.536 .442} \times 100 \% \\
= & 60,58 \% \\
& \text { Artinya angka diatas menggambarkan bahwa Bank Mandiri }
\end{aligned}
$$
menghasilkan laba sebelum pajak dengan menggunakan nilai ROA sebesar 60,68\% dengan arti bahwa setiap Rp 100 aktiva yang dimilikinya, Bank Mandiri mampu menghasilkan laba bersih sebelum pajak sebesar Rp 0,6068. Artinya Bank Mandiri sudah efisien atau dapat dikatakan baik, karena sudah mencapai standar dari ketentuan PBI No. 15/7/PBI/2013 berlaku sejak 1 Oktober 2013 yaitu sebesar 5,08, karena semakin tinggi nilai ROA, maka semakin efisien pula bank dalam memanfaatkan aktiva untuk menghasilkan keuntungan sebelum pajak.

\section{Analisis Terhadap Return On Equity (ROE)}

ROE merupakan perbandingan antara laba bersih dengan modal sendiri. Rasio ini merupakan indikator yang sangat penting bagi pemegang saham dan calon investor untuk mengukur kemampuan bank dalam memperoleh laba bersih yang dikaitkan dengan pembayaran deviden. Semakin tinggi rasio ini maka semakin baik, karena memberikan tingkat pengembalian yang besar kepada pemegang saham memberikan tingkat pengembalian yang besar kepada pemegang saham. Menurut ketentuan PBI No. 15/7/PBI/2013 berlaku sejak 1 Oktober 2013 tingkat penilaian kesehatan Rasio Rentabilitas Bank pada ROE yaitu dengan skor minimal 8,32\%. Berdasarkan data yang di peroleh ROE Bank Mandiri pada tahun 2017-2019 ditunjukan pada tabel dibawah ini.

\section{Tabel 3}

Laba Bersih SetelahPajak dan Modal Sendiri

\section{Bank Mandiri}

Tahun 2017-2019

(Dalam Rupiah)

\begin{tabular}{|l|c|c|c|}
\hline \multicolumn{1}{|c|}{ Komponen } & $\mathbf{2 0 1 7}$ & $\mathbf{2 0 1 8}$ & $\mathbf{2 0 1 9}$ \\
\hline $\begin{array}{l}\text { a. Laba Bersih Setelah } \\
\text { Pajak }\end{array}$ & 20.010 .716 & 24.078 .838 & 25.449 .980 \\
\hline b. Modal Sendiri & 39.745 .030 & 39.920 .792 & 40.340 .318 \\
\hline
\end{tabular}

Sumber: www.ojk.go.id

$R O E=\frac{\text { Laba Setelah Pajak }}{\text { Modal Sendiri }} \times 100 \%$

1. Perhitungan ROE Tahun 2017

$$
\begin{aligned}
R O E & =\frac{\operatorname{Rp~} 20.010 .716}{R p 39.745 .030} \times 100 \% \\
& =50,35 \%
\end{aligned}
$$

Artinya angka diatas ROE pada Bank Mandiri pada tahun 2017 dapat dikatakan efisien dalam melakukan kegiatan operasinya, ini dapat dilihat dari nilai ROE sebesar Rp 60,35\% dengan arti bahwa setiap Rp 100 modal yang dimiliki, maka bank mampu menghasilkan laba setelah pajak 
sebesar 0.5035. Dimana ROE Bank Mandiri dapat dikatakan baik karena bank tersebut sudah mencapai standar ketentuan BI yaitu sebesar 8,32\%.

2. Perhitungan ROE Tahun 2018

$$
\begin{aligned}
R O E & =\frac{\operatorname{Rp} 24.078 .838}{\operatorname{Rp~} 39.920 .792} \times 100 \% \\
& =60.32 \%
\end{aligned}
$$

Artinya angka diatas ROE Bank Mandiri pada tahun 2018 dapat dikatakan efisien dalam melakukan kegiatan operasinya, ini dapat dilihat dari nilai ROE sebesar Rp 60,35\% dengan arti bahwa setiap Rp 100 modal yang dimiliki, maka bank mampu menghasilkan laba setelah pajak sebesar 0.6035. Dimana ROE Bank Mandiri dapat dikatakan baik karena bank tersebut sudah mencapai standar ketentuan BI yaitu sebesar $8,32 \%$.

3. Perhitungan ROE tahun 2019

$$
\begin{aligned}
R O E & =\frac{\mathrm{Rp} 25.098 .065}{\mathrm{Rp} 40.340 .318} \times 100 \% \\
& =60,22 \%
\end{aligned}
$$

Artinya angka diatas ROE pada Bank Mandiri pada tahun 2019 dapat dikatakan efisien dalam melakukan operasinya, ini dapat dilihat dari nilai ROE sebesar Rp 60,22\% dengan arti bahwa setiap Rp 100 modal yang dimiliki, maka bank mampu menghasilkan laba setelah pajak sebesar 0,6022. Dimana ROE Bank Mandiri dapat dikatkan baik karena bank tersebut sudah mencapai standar ketentuan BI yaitu sebesar $8,32 \%$.

\section{Analisis Terhadap Net Profit Margin (NPM)}

NPM merupakan perbandingan antara laba bersih setelah pajak dengan pendapatan, dengan semakin besar tingkat NPM maka kinerja perusahaan dapat semakin produktif. Hal ini dapat berdampak meningkatkan kepercayaan investor untuk menambahkan modalnya pada perusahaan tersebut. Menurut ketentuan PBI No. 15/7/PBI/2013 berlaku sejak 1 Oktober 2013 tingkat penilaian kesehatan Rasio Rentabilitas Bank pada NPM yaitu dengan skor minimal 3,92\%. Berdasarkan data yang diperoleh NPM Bank Mandiri pada tahun 2017-2019 ditunjukan pada tabel dibawah ini.

Tabel 4

Laba Bersih Setelah Pajak dan Pendapatan Operasional

Bank Mandiri

Tahun 2017-2019

(Dalam Rupiah)

\begin{tabular}{|c|c|c|c|}
\hline Komponen & $\mathbf{2 0 1 7}$ & $\mathbf{2 0 1 8}$ & $\mathbf{2 0 1 9}$ \\
\hline $\begin{array}{l}\text { a. Laba Bersih Setelah } \\
\text { Pajak }\end{array}$ & 20.010 .716 & 24.078 .838 & 25.449 .980 \\
\hline $\begin{array}{l}\text { Jumlah Pendapatan } \\
\text { Bunga Lainnya }\end{array}$ & 44.667 .272 & 46.294 .391 & 50.321 .559 \\
\hline $\begin{array}{l}\text { Pendapatan } \\
\text { Operasional Lainnya }\end{array}$ & 19.571 .442 & 15.017 .515 & 17.948 .383 \\
\hline $\begin{array}{l}\text { Jumlah Pendapatan } \\
\text { operasional }\end{array}$ & 64.238 .714 & 61.311 .906 & 68.269 .942 \\
\hline
\end{tabular}

Sumber: www.ojk.go.id 
Dengan Formula:

$N P M=\frac{\text { Laba Bersih Setelah Pajak }}{\text { Total Pendapatan Operasional }} \times 100 \%$

Pendapatan Operasional $=$ Jumlah Pendapatan Bunga Bersih + Pendapatan

1. Perhitungan NPM 2017

Operasional lainnya

$$
\begin{aligned}
N P M & =\frac{\operatorname{Rp} 25.098 .065}{\operatorname{Rp} 64.238 .714} \times 100 \% \\
& =\operatorname{Rp~39.07\% }
\end{aligned}
$$

Artinya angka diatas kemampuan Bank Mandiri sangat baik dalam menghasilkan keuntungan sebesar Rp 39,07\%, bank ini sudah mencapai standar ketentuan dari BI yaitu sebesar Rp 3,92\%, dimana bank ini dapat dikatakan baik dalam mengukur kemampuan pendapatan operasional dalam menghasilkan laba.

2. Perhitungan NPM 2018

$$
\begin{aligned}
N P M & =\frac{\operatorname{Rp~} 31.320 .082}{\operatorname{Rp} 61.311 .906} \times 100 \% \\
& =51,08 \%
\end{aligned}
$$

Artinya angka diatas kemampuan Bank Mandiri sangat baik dalam menghasilkan keuntungan sebesar Rp 51,08\%, dimana bank ini sudah mencapai standar ketentuan BI yaitu sebesar 3,92\%, bank ini dapat dikatakan baik dalam mengukur kemampuan pendapatan operasional dalam menghasilkan laba.

3. Perhitungan NPM 2019

$$
\begin{aligned}
N P M & =\frac{\operatorname{Rp} 32.430 .770}{\operatorname{Rp} 68.269 .942} \times 100 \% \\
& =47,50 \%
\end{aligned}
$$

Artinya angka diatas kemampuan Bank Mandiri sangat baik dalam menghasilkan keuntungan sebesar Rp 47,50\%, dimana bank ini sudah mencapai standar ketentuan BI yaitu sebesar 3,92\%, bank ini dapat dikatakan baik dalam mengukur kemampuan pendapatan operasional dalam menghasilkan laba.

\section{SIMPULAN}

Berdasarkan hasil analisis diatas, gambaran pada tingkat Rentabilitas pada Bank Mandiri selama periode tahun 2017 - 2019 dapat disimpulkan bahwa:

a. Return on Asset (ROA) yang dimiliki oleh Bank Mandiri dari tahun 2017 sampai dengan tahun 2019 berada pada posisi yang sehat, karena pada tahun tersebut bank sudah memenuhi ketentuan standar minimum BI.

b. Return on equity (ROE) pada Bank Mandiri, pada periode 2017 sampai 2019 berada pada kondisi sehat, karena pada periode tersebut bank dapat efisien memperoleh laba dan sudah masuk pada ketentuan standar BI.

c. Net Profit Margin (NPM) yang ada pada Bank Mandiri pada periode 2017 sampai 2019 mengalami kenaikan dan bank dapat dikatakan baik dalam memperoleh laba dengan baik. 


\section{UCAPAN TERIMA KASIH}

Terimakasih penulis sampaikan kepada :

1. Orang tua ku tercinta Ayah (Bankri) dan Ibu (Epiriani), terima kasih yang tak terhingga atas segala doa, nasehat dan motivasinya baik moril maupun materil selama ini, serta selalu sabar mendampingiku dalam segala hal, sehingga penulis dapat menyelesaikan tugas akhir ini dengan baik. Untuk saat ini hanya karya ilmiah inilah yang dapat penulis persembahkan, semoga akan ada persembahan yang me mb u at ayah dan ibu bangga nantinya, amin.

2. Ibu Afriyeni, SE, MM selaku direktur AKBP Padang yang telah memberikan fasilitas dan kemudahan kepada penulis sehingga studinya dapat berjalan dengan lancar.

3. Bapak Doni Marlius SE, MM selaku ketua program studi Keuangan dan Perbankan AKBP Padang.

4. Bapak Yosep Eka Putra SE,MSi dosen pembimbing yang telah membimbing penulis selama ini.

5. Bapak jhon Fernos SE.MM selaku Dosen Penasehat Akademik, Program Studi Keuangan dan Perbankan "Pembangunan" AKBP Padang.

6. Bapak-bapak dan ibu-ibu dosen/staff pengajar pada AKBP-STIE "KBP" Padang, karyawan/i dan segenap seluruh akademika yang telah membantu penulis selama menempuh pendidikan di kampus ini.

\section{DAFTAR PUSTAKA}

Afriyeni. (2013). Analisis Pengaruh Pemberian Kredit Terhadap Profitabilitas PT. Bank Pembangunan Daerah (BPD) Sumatera Barat. AKBP Padang, 1(2), 95-107.

Arifin, I. Z., \& Marlius, D. (2017). Analisis Kinerja Keuangan PT. Pegadaian Cabang Ulak Karang. https://doi.org/10.31227/osf.io/n2peu

Azizah, Kertahadi, \& Yaningwati, F. (2013). Analisis Kinerja Keuangan Perusahaan (Perbandingan Penggunaan Analisis Rasio Keuangan Dan DU Pont System) ( Studi pada PT . Unilever Indonesia , Tbk dan Anak Perusahaan yang Terdaftar di Bursa Efek Indonesia Periode 2007-2013 ). Fakultas Ilmu Administrasi Universitas Brawijaya, 25(2), 1-9.

Badria, M., \& Marlius, D. (2019). Analisis Rasio Likuiditas Pada PT. Bank Perkreditan Rakyat (BPR) Lengayang. Akademi Keuangan Dan Perbankan Padang, 1-11.

Dini, A. W., \& Indarti, I. (2010). Pengaruh Net Profit Margin ( NPM ), Return On Assets ( ROA ) Dan Return On Equity ( ROE ) Terhadap Harga Saham Yang Terdaftar Dalam Indeks Emiten LQ45 Tahun 2008 - 2010 The influence of Net Profit Margin ( NPM ), Return On Assets ( Roa ), and Return On Eq. Sekolah Tinggi Ilmu Ekonomi Widya Manggala, 1-18.

Fernos, J. (2017). Analisis Rasio Profitabilitas untuk mengukur kinerja PT. Bank Pembangunan Daerah Sumatera Barat. Akademi Keuangan Dan Perbankan "Pembangunan," 1(2), 107-118.

Fernos, J., \& Dona, E. (2018). Analisis Loan To Deposit Ratio , Capital Adequacy Ratio dan Return On Assets PT . Bank Pembangunan Daerah Sumatera 
Barat. Akademi Keuangan Dan Perbankan Padang, 2(2), 107-118.

Gammahendra, F., Hamid, D., \& Riza, M. F. (2014). Pengaruh Struktur Organisasi terhadap Efektivitas Organisasi. Fakultas Ilmu Administrasi Universitas Brawijaya Malang, 7(2), 1-10.

Handayani, M., \& Marlius, D. (2017). Analisis Tingkat Kesehatan PT. BPR Batang Kapas. https://doi.org/10.31227/osf.io/bq48z

Hapsak, H. W. P. (2018). Analisis Likuiditas, Solvabilitas, Dan Rentabilitas Terhadap Nilai Perusahaan (Studi kasus pada perusahaan Food and Beverage yang terdaftar di Bursa Efek Indonesia tahun 2014-2017 ). FAKULTAS EKONOMI DAN BISNIS UNIVERSITAS MUHAMMADIYAH SURAKARTA.

Hardi, J., \& Fernos, J. (2008). Analisis LDR Dan NPL PT. Bank Nagari Cabang Pembantu Tarusan Kabupaten Pesisir Selatan. Akademi Keuangan Dan Perbankan "Pembangunan” Jhonfernos@akbpstie.ac.id ABSTRACT, 110.

Maith, H. A. (2013). Analisis Laporan Keuangan Dalam Mengukur Kinerja Keuangan Pada PT. Hanjaya Mandala Sampoerna TBK. Fakultas Ekonomi Dan Bisnis, Jurusan Akuntansi Universitas Sam Ratulangi Manado Email:, 1(3), 619-628.

Marlius, D., \& Sukma, J. (2020). Analisis Tingkat Kesehatan Bank Pt. Bank Perkreditan Rakyat Jorong Kampung Tangah Pariaman Cabang Padang. https://doi.org/10.31219/osf.io/dmjy5

Mila Mirza, A. (2019). Analisis Rasio Rentabilitas Pada PT. Bank Pembangunan Daerah (BPD) Sumatera Barat Cabang Utama Padang. Akademi Keuangan Perbankan Dan "Pembangunan" (AKBP) Padang, 1-12.

Muhammad Albahi. SE., M. S. (2015). Analisis Rasio Likuiditas, Rasio Rentabilitas, Rasio Solvabilitas Pada Kinerja Keuangan PT. Bank Sumut Cabang Pirngadi Medan. 1(2).

Mustika, S., \& Marlius, D. (2019). Analisa Tingkat Kesehatan Keuangan PT. Bank Perkreditan Rakyat (BPR) Batang Palangki. https://doi.org/10.31219/osf.io/wupyh

Ottay, M. C., \& Alexander, S. W. (2015). Analisis Laporan Keuangan untuk Menilai Kinerja Keuangan Pada PT> BPR Citra Dumoga Manado. Fakultas Ekonomi Dan Bisnis, Jurusan Akuntansi Universitas Sam Ratulangi Manado, 3(1), 923-932.

Pradnyani, N. K. A., Ustriyana, N. G., \& Anggreni, G. A. A. L. (2017). Analisis Kinerja Keuangan berdasarkan Rasio Keuangan pada PT . BPR . Saptacristy Utama. Program Studi Agribisnis, Fakultas Pertanian, Universitas Udayana, 6(1), 142-151.

Putri, Y. A., \& Marlius, D. (2018). Analisis Tingkat Kesehatan Bank Pada PT. Bank Perkreditan Rakyat (BPR) Jorong Kampuang Tangah Pariaman Cabang Padang. https://doi.org/10.31227/osf.io/r98pv

Rahmayeli, D. S., \& Marlius, D. (2017). Analisis Kinerja Keuangan Pada PT. Bank Perkreditan Rakyat (BPR) Batang Kapas Pesisir Selatan. https://doi.org/10.31227/osf.io/sz5db

Rohayati, S., \& Fernos, J. (2009). Analisis Profitabilitas Pada PT. Bank 
Pembangunan Daerah Sumatera Barat. Akademi Keuangan Perbankan "Pembangunan" Padang, 1-7.

Roza, S. H. M., \& Fernos, J. (2014). Analisis Perbandingan Rasio Rentabilitas Pada PT. BPD Sumatera Barat Tahun 2012-2014. Akademi Keuangan Perbankan "Pembangunan" Padang, 1-11.

Sarah Arnila, J. F. (2018). Sistim Pengendalian Kredit Untuk Mempertahankan Likuiditas Pada PT. Bank Nagari Cabang Painan. Akademi Keuangan Perbankan “Pembangunan”Padang Jhonfernos@akbpstie.ac.id, 1-13.

Sumitra, M. A., \& Ibrahim, M. (2016). Analisis Rasio Rentabilitas Dan Rasio Likuiditas Pada Bank BUMN Yang Terdaftar Di Bursa Efek Indonesia Tahun 2008-2014. Kampus Bina Widya KM 12,5 Simpang Baru Panam Pekanbaru 28293- Telp/Fax. 0761-63277, 1-11.

Tanor, M. O., Sabijono, H., \& Walandiuw, S. K. (2015). Analisis Laporan Keuangan Dalam Mengukur Kinerja Keuangan Pada PT. Bank Artha Graha Internasional, tbk. Fakultas Ekonomi Dan Bisnis, Jurusan Akuntansi Universitas Sam Ratulangi Manado, 3(3), 639-649. 